Jurnal The Messenger, Vol. 11, No. 1A, Special Issue on the School of Multimedia Technology and Communication Postgraduate Symposium, pp. 138-147

P-ISSN: 2086-1559, E-ISSN: 2527-2810

\title{
Effect of Press Freedom on Sudanese Newspapers Framing of Corruption Issues
}

\section{Pengaruh Kebebasan Pers pada Pembingkaian Surat Kabar-surat kabar di Sudan atas Isu Korupsi}

\author{
Yassin Bashir Hamid ${ }^{1}$, Rosli Mohammed ${ }^{1}$, Mohd. Khairie Ahmad \\ ${ }^{1}$ School of Multimedia Technology and Communication, Universiti Utara Malaysia, \\ Sintok, Kedah, Malaysia \\ *Corresponding author, e-mail: yassinhamed@ hotmail.com
}

\begin{abstract}
This research aims at exploring the effect of the press freedom on the newspapers' framing of the issue of corruption in Sudan. A qualitative method was adopted using in-depth interviews to adequately explore the perspectives of the Sudanese journalists and editors towards the press freedom effect on the Sudanese newspapers in terms of framing the issues of corruption. A purposeful sampling was employed in selecting 20 Sudanese journalists and editors across both the governmental and private newspapers. Therefore, the study has significantly contributed to the overall perspectives of how newspapers framing affects public awareness about corruption and possible remedies in Sudan. The findings revealed that the legislation is significant in developing the press industry which has a great role in addressing the issues of corruptions.

Keywords: Press Freedom, Framing, Corruption Issues, Sudanese Newspapers.
\end{abstract}

\section{Abstrak}

Penelitian ini bertujuan untuk mengeksplorasi pengaruh kebebasan pers pada pembingkaian surat kabar-surat kabar tentang masalah korupsi di Sudan. Metode kualitatif diadopsi dengan menggunakan wawancara mendalam untuk mengeksplorasi secara memadai perspektif jurnalis dan editor Sudan terhadap efek kebebasan pers pada surat kabar Sudan, dalam hal membingkai isu-isu korupsi. Pengambilan sampel dilakukan untuk memilih 20 jurnalis dan editor Sudan baik surat kabar pemerintah dan swasta di Sudan. Oleh karena itu, penelitian ini telah memberikan kontribusi signifikan terhadap perspektif keseluruhan tentang bagaimana pembingkaian surat kabar mempengaruhi kesadaran publik tentang korupsi dan kemungkinan perbaikan di Sudan. Temuan mengungkapkan bahwa undang-undang penting dalam mengembangkan industri pers yang memiliki peran besar dalam menangani masalah korupsi.

Kata Kunci: Kebebasan Pers, Pembingkaian, Isu Korupsi, Surat Kabar di Sudan.

\section{Introduction}

The issue of financial corruption has become widely spread in the third world countries, specifically in the African continent that has suffered a great deal of corruption. Sudan as an African country is no exception to this rule. There is no doubt that strong media that have freedom to exercise their role in monitoring the government's performance, criticizing the incompetent government officials, and revealing the corruption of the elites is necessary. Significantly, this study adds specifically to the understanding of newspaper coverage of corruption in Sudan and how that coverage helps create a sense of predictability on corruption issues. Corruption has several different aspects, but the most controversial type is corruption in governance, that is the financial corruption. The term 'corruption' originally means that the system of governance was 
transformed from a good and stable system into a system that failed to achieve an end to its people and mismanagement (Glaeser \& Goldin, 2007). According to Dike (2005), corruption is defined as efforts to secure wealth or power through illegal means at the expense of the public. Corruption can be also an abuse of the public power to obtain personal benefits. Financial corruption is specifically defined as misusing the official power for personal gains (Svensson, 2005). Such corruption can include the manipulation of the government's assets through sale, embezzlement of the government funds, and the acceptance of bribes. Corruption as a global threat to the development of nations, negatively affects people's pension; therefore, the spread of corruption has made its devastating effects more clear in Africa. In other words, Africa is the most corrupted continent in the world (Fombad \& Fombad, 2015; Lawal, 2007). Khan (2007) noted that despite the presence of oil and rapid mineral resources in many African countries, such as Angola, Chad, the Democratic Republic of the Congo, Nigeria and Sudan, citizens of these countries continued to decline to high levels of poverty rather than having the living standards.

Among the African countries, Sudan is one of the most corrupted countries according to a report by (US Department of State, 2016). Sudan ranks seventh out of 183, with 1.6 points on a 10-point scale for corrupted countries. In this regard, the 2011 Citizens Survey Barometer of Global Corruption reported that $67 \%$ of the Sudanese citizens believe that there has been an increase in corruption in Sudan over the last three years prior to the survey (International, 2016). The reports Transformation Index BTI (2016) also confirmed that Sudan has failed to eliminate corruption because of its poor management, lack of political will, and a clear distinction between the state and the ruling party. For example, according to the Freedom House (2016) polled by States for the transfer of political and civil rights and freedoms, including press freedom, Sudan is classified as the 'worst worst' among the world's 12 worst nations. According to Mauro (2004), financial corruption is deeply rooted in the Sudanese governance to the extent that the politicians receive a high bribe, resulting in greater inequalities and poor economic performance, thus leading to the government's collapse (Abu \& Abd Karim, 2015).

Media coverage, as Nogara (2009) asserts, can easily direct people towards the issues of corruption among the politicians, thus leading to the defeat of these politicians in elections or even the collapse of the entire government. This media coverage can also push people to have their pressure on the ruling regime to reform laws and regulations that likely cause corruption behavior. Nogara (2009) points out that media can play a big role in publishing stories which not only assess the most controversial issues such as financial corruption in the government sector but also reveals corruption and other shortcomings and weaknesses in the public institutions, such as courts, police and anticorruption agencies. These roles played by the media will put pressure on the governments for making political and legislative reforms that prevent corruption in the government's financial sector.

The present study identifies the impact of weak press freedom because of the restrictions imposed by the authoritarian regime, such as censorship, restricted laws, lack of access to the government's data on framing issues of financial corruption in the government sector, and how the Sudanese press play their role as investigative journalism to combat financial corruption in the country. Although Sudan has a large number of local and national newspapers, insufficient attention has been paid to issues of financial corruption. The main reason for the inefficiency is that all sources of information on which the media rely are often under the control of the state, the ruling elite (Muzzatti \&

Jurnal The Messenger, Vol. 11, No. 1A, Special Issue on the School of Multimedia Technology and Communication Postgraduate Symposium, pp. 138-147 
Featherstone, 2007). In addition, journalists who report the government's weak performance were under the intense pressure, thus exposing their press to be closed or arrest.

Few studies have addressed media coverage regarding corruption in the governance in Sudan. Previous studies showed only the relationship between good governance in countries and active media coverage of policy (Ahrend, 2002). Other studies have found a relationship between media coverage and voter's knowledge (Snyder \& Strömberg, 2010). Previous studies have focused on the role of media to curb corruption (Sowunmi, Raufu, Oketokun, Salako, \& Usifoh, 2010; Stapenhurst, 2000) or the relationship between press freedom and corruption (Ahrend, 2002; Becker, Naab, English, \& Vlad, 2013; Brunetti \& Weder, 2003; Fardigh, 2007; McConnell \& Becker, 2002; Sani, 2014; Sowunmi et al., 2010). Other studies have focused on the government's advertising and its relationship with the media coverage of corruption scandals (Tella, R. D., \& Franceschelli, 2009), whereas (Motlhasedi \& Phiri, 2015) focused on the impact of mass media on corruption in South Africa. However, few limited studies have focused on newspapers' framing of the issues of corruption. Therefore, the present study focuses on how the Sudanese newspapers frame the news of issues of corruption in Sudan.

Therefore, this study expands understanding and views on how media frame corruption issues, thus leading to the development of future policies and solutions. The study has significantly contributed to the overall perspectives of how newspapers framing affects public awareness about corruption and possible remedies in Sudan. Also, how the the freedom of the press influences the content of the newspaper.

The present study aims at applying the theories of media framing to identify the way of the coverage of issues of corruption in the Sudanese Press. The focus is on the internal factors that affect framing the news. These include issues of the editorial policies and news values. The study examines the external factors, such as the ownership, the legislation, and the access to the government's information and economic interests in relation to framing and the coverage of the issues of corruption in Sudan. The study also addresses the issue of corruption in Sudan within the context of the Sudanese press by investigating how the Sudanese press frame the coverage of issues of corruption in Sudan. This was achieved through the content analysis of four Sudanese newspapers, focusing mainly on their coverage of the issues of corruption. The time period for the study covers from April 2014 to April 2015. The newspapers included Aldar, Al Intibaha, Assayha and Sudan Vision Daily which are all daily newspapers that publish letters by the editors as well as news events that reflect the views on newspapers' coverage of the issues of corruption in Sudan.

The findings of this paper are important theoretically and practically to the body of knowledge and research society. It is also important to understand the audience as recipients and interact with framing news that will serve the governments, the educators, coaches and media editors. Therefore, the present study expands our understanding and views of the impact of the freedom of the press on how media frame the financial corruption issues, thus leading to the development of policies and future solutions.

\section{Methodology}

A qualitative research method was adopted, using in-depth interviews to adequately probe the perspectives of the Sudanese journalists and editors then to explore the effect of the law on press freedom, censorship and restrictive laws. Also, the difficulties to access the government's information by the Sudanese newspapers' in framing the issues 
of corruption in Sudan was examined. A purposeful sampling technique was adopted in selecting 20 Sudanese journalists across both governmental and private newspapers in Sudan. In order to achieve clearer understandings of the journalists' perspectives, the study supports each theme with models generated by means of employing NVivo 8 software.

The period from April 2016 to March 2017 was selected for this study because the Sudanese citizens during that period experienced very difficult political conditions due to the third anniversary of the demonstrations in September 2013, whereby a number of demonstrators was killed. Second, there was a significant increase in the rate of financial corruption in Sudan. For example, the emergence of the most famous judge of financial corruption, the issue of financial corruption in the office of the governor of Khartoum State, the largest city and the capital of Sudan, have not been exposed to trials.

The cases of financial corruption in the office of the governor of Khartoum state and the issue of corruption in Sudan Cotton Company took place during this time. The four newspapers selected in the present study are considered national ones (NCPP, 2016). Three of the selected newspapers, namely Aldar, Al Intibaha and Assayha are in Arabic, whereas only Sudan Vision Daily is in English. These newspapers were selected because they are highly circulated in Sudan. For instance, Aldar has 29,977 circulations since May, 1994. Al Intibaha has 24, 779 circulations since October, 2005. Finally, Assayha has managed between 11 and 14 thousand circulations since its first production in 2014. As for Sudan Vision Daily newspaper, it is selected solely because it is the most popular English language newspapers in Sudan and has about 1 to 2 thousand circulations since August, 2003.

The first stage of the study is the dual process of development and testing the interview protocol and interview questions in order to meet the objectives of the present study. McNamara (2009), a setting with little distraction in the course of the interviews was selected. Second, the purpose of the interview was explained to all the interviewees as well as the assurance of confidentially. Finally, each of the interviewees had the opportunity to ask for clarification or give suggestions that can help conduct the interview.

According to Kvale (2007), a pilot study can assist the researcher in identifying if there are mistakes or other weaknesses in the interviews design. The interview protocol was designed to elicit rich data to all the research questions, but at the same time, all the questions were framed to be flexible and easy to be understood. Creswell (2012) stressed that the interview questions should be constructed in such a way to keep the participants focus on the questions under exploration.

Table 1. Informants' Background (source: Author's analysis, 2018)

\begin{tabular}{ccc}
\hline Informants & Newspapers & Position \\
\hline Informant 1 & AL-Intibaha & Journalist \\
Informant 2 & AL-Intibaha & Journalist \\
Informant 3 & AL-Intibaha & Journalist \\
Informant 4 & AL-Intibaha & Journalist \\
Informant 5 & AL-Intibaha & Journalist \\
Informant 6 & AL-Intibaha & Editor \\
Informant 7 & Assyha & Journalist \\
Informant 8 & Assyha & Journalist \\
Informant 9 & Assyha & Journalist \\
Informant 10 & Assyha & Journalist
\end{tabular}

Jurnal The Messenger, Vol. 11, No. 1A, Special Issue on the School of Multimedia Technology and Communication Postgraduate Symposium, pp. 138-147 
Informant 11

Informant 12

Informant 13

Informant 14

Informant 15

Informant 16

Informant 17

Informant 18

Informant 19

Informant 20

$\begin{array}{cc}\text { AL-Dar } & \text { Editor } \\ \text { AL-Dar } & \text { Editor } \\ \text { AL-Dar } & \text { Editor } \\ \text { Sudan Vision } & \text { Journalist } \\ \text { Sudan Vision } & \text { Journalist } \\ \text { AL-Intibaha } & \text { Editor } \\ \text { Assyha } & \text { Editor } \\ \text { Assyha } & \text { Editor } \\ \text { Sudan Vision } & \text { Journalist } \\ \text { AL-Dar } & \text { Journalist }\end{array}$

The selection of the sample for this study was based on a purposeful sampling procedure. In qualitative researches, according to Yin (2011), cases are mostly examined through a purposeful sampling. Guest, Bunce, and Jhonson (2006), noted that, for a research that aims at exploring the opinions and studying the involvement of moderately standardized individual, 12 interviewees are considered appropriate. Hence, in the present study, twenty interviewees (three journalists or editors from each newspaper) were selected.

Selecting rich information participants is the most important criteria in qualitative studies (Czaja \& Blair, 2005). Therefore, the researcher in the present study employed the following criteria in selecting the participants.

1. The interviewee must have considerable level of skills, experience and expertise in news editorial and news writing for a minimum of two years.

2. The interviewee agrees to participate in the interview.

In-depth interviews were used for the collection of data in the present study. In line with this, the interview questions were designed as open-ended questions which focused on the lived experience of editors and journalists and issues of corruption in Sudan. It also allowed the interviewer to ask probing questions as means of follow up. Therefore, the attached interview guide is drafted for the data collection. According to Kajornboon (2005), the interview guide encompasses the topic, questions and issues be to covered during the interviews.

All the interviews were recorded using a digital voice recorder and notes were also taken during the interviews to focus on the most important issues raised by the participants. The tape recording is one of the best devices for collecting data of any interview (Creswell, 2012; Yin, 2011).

A thematic analysis was used. The interview questions were divided into the following themes: corruption, forth state or watchdog, ownership, internal factors and external factor. NVIVO 11 (a data management software for qualitative data analysis) was used to simplify the process of storing, coding, analysis and preparation of the graphical representation of data. By using Nvivo 11 the process is faster, accurate and easier for the researcher to handle the several different codes. Nvivo 11 is also used to identify different relationships and produce diagrams of the emerging findings and the preparation of the research reports.

\section{Results and Discussion}

In modern times, control of the media and the control of information movement have been a source of concern for successive governments in various countries of the world (Okwuchukwu, 2014). The most important problem facing the press in the Arab countries including as discovered by this study is that the press laws offer very little 
guarantees for freedom of the press, whereas the same laws provide tougher criminal penalties against the media. According to Omu (2000), the problem of controlling the media is linked to the owners and interests of media institutions. This significantly hinders the media from performing their various functions. These laws usually include defamation laws, national unity, and the threat to national security.

Emerging also from the finding was that the Legislation and Press Freedom are one of the key elements of the development of press industry by the Sudanese government through the parliament to ensure press freedom. From the participants' perspectives, the legal obstacles including defamation laws, national unity and the threat to national security called the (Information Act, the Press Law, the Criminal Law) have restricted the press in their quest for access to information in spite of the approval of the freedom of information ACT (FOI).

The press industry in Sudan is directly related to the overall situation in the country. Thererfore, the effects as well as the influence do not come from one source. Based on the findings, advertising and economic interests are also discovered to be among the most important issues that have sprout from the interviews as an important part of the influence on press freedom. The views below show the participants' perceptions of the advertiser and economic influence on the issue of ownership's influence on corruption. According to Informant 1 the influence is noted thus:

"It is certain that advertising is one of the most important financial sources of the newspaper. If the newspaper is suspended for a day or two, the advertising will be blocked from this newspaper in this period, which negatively affects the income of the owner and the salaries of journalists" (Informant 1).

The press will not evolve if there is no comprehensive and complete reform of the system in the case of the Sudanese laws to be compatible with democracy, thus ensuring the appropriate legislative environment to provide freedom of the press and also ensure the existence of investigative journalism and the ability to address critical issues such as financial corruption in the public sector. As a solution to this, it was discovered by this paper that the state should release the restrictive laws such as National Security Act, the press law, the criminal law, and the law on informatics. In this regard, Informant 6 said: "First, it is proposed to amend the laws on publishing so that the newspapers can carry out their duties. Many of the measures taken in dealing with these cases are arbitrary. In addition, the press industry in Sudan is linked to the general situation in the country. In other words, the press will not develop if there is no Sudanese laws compatible with democracy, thus guaranteeing the freedom of the press."

The obstacles faced by the press institutions in the development of press industry in Sudan have not only hindered the press from performing their role professionally but also led the political elite and companies to manipulate editorial direction and news content directly and remotely. It has also been revealed that the collaborative efforts among the journalists need to be considered as part of the development of press industry in Sudan as suggested by the informants. For instance, Informant 12 corroborated this perception by saying that collaborative effort among journalists is imperative thus: "When you have a better work environment, the performance of press will be better. Also, if there is a collaboration between the owner of the newspaper and the editor of the newspaper and the leadership of the newspaper and the newspaper and the sources of official or popular and the working environment itself whenever there is harmony and there is an understanding between the staff of the newspaper, the work is better and existing."

Jurnal The Messenger, Vol. 11, No. 1A, Special Issue on the School of Multimedia Technology and Communication Postgraduate Symposium, pp. 138-147 
In the same vain, it has been revealed that the legislation and press freedom is one of the key elements of development of press industry by the Sudanese government through the parliament to ensure press freedom. Expressing his view on this Informant 10 stated: "The press industry in Sudan is not linked to the overall situation in the country. The press will not develop if there is no comprehensive and complete reform of the system in the Sudanese state of laws compatible with democracy, which guarantees freedom of the press and easy access to government information. The press industry needs to resort to the law and to codify the information."

The provisions of the Press and Publications Act of Sudan provide a wide range of freedom. For example, Article 5 of the Press and Publication Law 'Basic Principles of Freedom of the Press and Journalists' states:

1. The press should exercise freedom and be independent in accordance with the constitution and the law, taking into account the public interest, the rights, and the privacy of others without prejudice towards the public morals.

2. No restrictions are imposed on the freedom of press publication except under the provisions of the Law for the Protection of National Security, Order and Public Health. Newspapers will not be confiscated or closed or the journalists and publishers are not imprisoned due to the exercise of their profession except in accordance with the law.

The Interim National Constitution of 2005 guaranteed the protection of freedom of expression and freedom of the press under Article 39 and access to information for transparency, accountability, and efficiency. However, despite the previous constitutional provision and similar laws, access to information, in particular, public records and official documents, was not possible despite the Freedom of Information Act. The Sudanese government approved the Freedom of Information Act, which was also approved by the Sudanese Parliament in January 2015.

However, several factors limit the application and effectiveness of the Freedom of Information Act. The main obstacles are illiteracy and poverty; the majority of the population is either uneducated or ignorant of the implications of the Freedom of Information Act. Hence, people consider that the use of the Freedom of Expression Act should be practiced by a public institution, whereas individual practice of the Freedom of Information Act is time-wasting and unsuccessful. This confirms that having such laws is not enough to be applied practically. Therefore, the real desire of the government and citizens in the application of laws will be effective in providing freedom of expression and access to information and other values of freedom.

The institutions that would activate the Freedom of Information Act is the judicial institution and the judicial services that hinder progress on this issue. Thus, the law remains unenforceable in most federal states. It is equally important to reiterate the inappropriate position of public officials, who are still reluctant to provide required information, despite the adoption of the law, as well as a lack of awareness of the existence and importance of citizenship by citizens and journalists in particular.

The delay in the implementation of the Freedom of Information Act has hindered access to official documents and reduced the quest for accountability of officials in the public sector. Theoretically, the government claims that the government's documents are available for public scrutiny and that irregularities by public officials are making their way to justice. In fact, the official secrecy, the difficulty of access to the government's information, corruption and the broad powers of unconstitutional public officials undermine the institutionalization of practice. It is therefore recommended that the State 
of Sudan reviews the implementation of the Freedom of Information Act.

\section{Conclusion}

Media play an important role in the society and serve as an effective source of information and a powerful way of communicating. Writers and journalists use media frameworks to streamline information flow to readers. Framing at the basic level is a combination of words that constitutes a sentence, a phrase, or a story that is presented as a message to the audience. This message, which is provided by the media, has been subjected to research and analysis by analyzing the content part of the current study.

The results of the study confirmed that there is a clear difference between the newspapers in the way they present the news according to the tendencies, ideology and political color and according to the private interests, the interests of the stakeholders, companies, and the governmental officials which are all determined by the owners of these newspapers.

Therefore, the state should release the restrictive laws such as National Security Act, the press law, the criminal law and the law on informatics, activate and develop the laws provided by the country's national constitution to guarantee the basic human rights of freedom of thought, expression, press, and access to the government's information, thus strengthening the relationship between the government and its citizens and fighting corruption. In conclusion, the Sudanese press should raise awareness among citizens and journalists towards the importance of activating the law related to access to information, which was approved by the Sudanese parliament in January 2015. Its development and activation could achieve free access to information and raise the values of transparency and fighting corruption in the country. Future researchers should explore how the restrictions such as legislations and controlling of the media in Sudan limit the Sudanese newspapers in doing their role as watchdog on government's activities.

\section{Acknowledgements}

I acknowledge, with deep gratitude and appreciation, the inspiration, encouragement, supports, valuable time, mentoring and guidance given to me by my supervisor, Associate Professor Dr. Rosli bin Mohammed. Also, I am deeply indebted and grateful to Dr. Mohd. Khairie Ahmad, my co-supervisor, for his extensive guidance, continuous support.

\section{References}

Abu, N., \& Abd Karim, M. Z. (2015). The causal relationships among corruption, political instability, economic development and foreign aid: Evidence from the economic community of West African states. Journal of Applied Economic Sciences, 10(31), 20-33.

Ahrend, R. (2002). Press freedom, human capital and corruption.

Becker, L. B., Naab, T. K., English, C., \& Vlad, T. (2013). Measurement Issues and the Relationship Between Media Freedom and Corruption.

Brunetti, A., \& Weder, B. (2003). A free press is bad news for corruption. Journal of Public Economics, 87(7), 1801-1824.

Creswell, J. W. (2012). Educational Research: Planning, Conducting, and Evaluating Quantitative and Qualitative Research. Harlow: Pearson Education Limited.

Czaja, R., \& Blair, J. (2005). Designing Surveys: A Guide to Decisions and Procedures. Newbury Park, CA: Pine Forge Press.

Jurnal The Messenger, Vol. 11, No. 1A, Special Issue on the School of Multimedia Technology and Communication Postgraduate Symposium, pp. 138-147 
Dike, V. E. (2005). Corruption in Nigeria: A new paradigm for effective control. Africa Economic Analysis, 24(08), 1-22.

Fardigh, M. A. (2007). Press freedom and corruption: one of the mass media functions in promoting quality of government.

Fombad, C. M., \& Fombad, M. C.-A. (2015). 31 Rethinking Anti-Corruption Strategies in Africa: Constitutional Entrenchment as Basis for Credible and Effective AntiCorruption Clean-Ups. In Brill (Ed.), Shielding Humanity (pp. 726-773).

Freedom House. (2016). Freedom in the World 2016. In The Annual Survey of Political Rights and Civil Liberties. Rowman \& Littlefield.

Glaeser, E. L., \& Goldin, C. (2007). Corruption and Reform: Lessons from America's Economic History. Chicago: University of Chicago Press.

Guest, G., Bunce, A., \& Jhonson, L. (2006). How Many Interviews Are Enough? An Experiment with Data Saturation and Variability. Family Health International, 18(1), 59-82.

International, T. (2016). Global corruption report. In Sport. Routledge.

Kajornboon, A. B. (2005). Using interviews as research instruments. E-Journal for Research Teachers, 2(1).

Khan, F. (2007). Corruption and the Decline of the State in Pakistan. Asian Journal of Political Science, 15(2), 219-247.

Kvale, S. (2007). Doing interviews (Vol. 2). London: Sage.

Lawal, G. (2007). Corruption and development in Africa: challenges for political and economic change. Humanity and Social Sciences Journal, 2(1), 1-7.

Mauro, P. (2004). The persistence of corruption and slow economic growth. IMF Staff Papers, 51(1), 1-18.

McConnell, P. J., \& Becker, L. B. (2002). The role of the media in democratization. In Political Communication Section of the International Association for Media and Communication Research. Barcelona: International Association for Media and Communication Research.

McNamara, C. (2009). No Title. Retrieved January 11, 2010, from www.princetonkychamber.org/uploads/1/6/1/8/16185526/hr101.pdf

Motlhasedi, N., \& Phiri, A. (2015). The effects of mass media on corruption in South Africa: A MTAR-TEC persepctive. Economics Bulletin, 35(3), 1607-1616.

Muzzatti, S. L., \& Featherstone, R. (2007). Crosshairs on our backs: The culture of fear and the production of the DC sniper story. Contemporary Justice Review, 10(1), 43-66.

Nogara, M. (2009). Role of Media in Curbing Corruption: The Case of Uganda under President Yoweri K. Museveni during the 'No-Party' System (ST/ESA/2009/DWP/72 No. 72). New York. Retrieved from https://www.un.org/development/desa/publications/working-paper/role-of-mediain-curbing-corruption-uganda

Okwuchukwu, O. G. (2014). The influence of media ownership and control on media agenda setting in Nigeria. International Journal of Humanities Social Sciences and Education (IJHSSE), 1(7), 36-45.

Omu, F. (2000). The Nigerian press: Milestones in service. In Hosting the 140th Anniversary of the Nigerian Press. Lagos: Solasprint (Nigeria) Ltd.

Sani, A. A. (2014). Press Freedom: Analyzing the portrayal of Nigerian-State on National dailies cover-page headlines. Journal of Yaşar University, 9(35), 6255-6260.

Snyder, J. M., \& Strömberg, D. (2010). Press coverage and political accountability. 
Journal of Political Economy, 118(2), 355-408.

Sowunmi, F., Raufu, A., Oketokun, F., Salako, M., \& Usifoh, O. (2010). The role of media in curbing corruption in Nigeria. Research Journal of Information Technology, 2(1), 7-23.

Stapenhurst, R. (2000). The media's role in curbing corruption (No. 21024). Retrieved from http://documents.worldbank.org/curated/en/893191468766225068/Themedias-role-in-curbing-corruption

Svensson, J. (2005). Eight questions about corruption. The Journal of Economic Perspectives, 19(3), 19-42.

Tella, R. D., \& Franceschelli, I. (2009). Government advertising and media coverage of corruption scandals. American Economic Journal: Applied Economics, American Economic Association, 3(4), 19-51. https://doi.org/10.3386/w15402

Transformation Index BTI. (2016). BTI 2016 Regional Report South and East Africa. Retrieved February 19, 2019, from https://www.btiproject.org/fileadmin/files/BTI/Downloads/Reports/2016/pdf_regional/BTI_2016 _Regionalbericht_SEA.pdf

US Department of State. (2016). Investment Climate Statements for 2016 Sudan. Retrieved February 19, 2019, from ttps://www.state.gov/e/eb/rls/othr/ics/2016investmentclimatestatements/index.htm ?year $=2016 \&$ dlid $=254249$ \#wrapper

Yin, R. K. (2011). Applications of case study research (3rd ed.). London: Sage Publications Inc. 